\title{
Induction Therapy: A Modern Review of Kidney Transplantation Agents
}

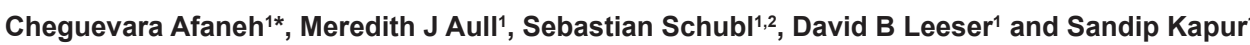

${ }^{1}$ Department of Surgery, Division of Transplantation, NewYork-Presbyterian Hospital/Weill Cornell Medical College, New York, USA

${ }^{2}$ Department of Surgery, Jamaica Hospital, New York, USA

\begin{abstract}
Kidney transplantation remains the most effective modality for the treatment of end-stage renal disease. The development of induction therapy has significantly reduced the incidence of acute rejection within the first six months following kidney transplantation. As a result, induction therapy is typically administered in the majority of kidney transplants. Moreover, early graft function has also improved with the advent and routine administration of induction therapy. Effective induction therapy has also expanded the donor pool as it allows for more effective utilization of marginal donor kidneys including expanded criteria donors and donors after cardiac death. It may also benefit higher immunologic risk recipients such as highly sensitized, African American, and repeat transplant patients. Poly- and monoclonal antibody agents are available for use as induction agents, including rabbit Anti-thymocyte globulin, interleukin-2 receptor antagonists, and alemtuzumab each of which have proven efficacy but have discrete advantages and disadvantages. Tailoring induction therapy to individual patient profiles provides the best opportunity for both short and long-term outcomes of the patient and allograft. Moreover, we explore the role of induction therapy with long-term steroid avoidance immunosuppression regimens in modern kidney transplantation. Overall, we review the safety and efficacy of this important group of induction agents and discuss an approach to tailoring their use for specific patients undergoing kidney transplantation.
\end{abstract}

\section{Introduction}

Historically, acute rejection episodes were most prevalent in the early postoperative period. Prior to induction therapy, kidney transplantation was plagued with high rates of acute rejection. Early attempts at preventing acute rejection consisted only of glucocorticoids and azathioprine. However, advancements in the understanding of kidney transplantation immunology lead to the development of "induction therapy." Induction therapy refers to any potent immunosuppressive agent administered in the perioperative period to prevent episodes of acute rejection and immunologically-mediated causes of graft loss. The widespread use of these agents has significantly decreased the incidence of acute rejection in the first six months; however, long-term allograft survival has not yet been prolonged by the agents used in modern kidney transplantation [1].

In 1995 induction therapy was used in less than half of all kidney transplants in the United States, a decade later, approximately $70 \%$ of all kidney transplant recipients received induction therapy [2]. Induction therapy carries various risks, the most serious of which is overimmunosuppression resulting in infection or malignancy $[3,4]$. Appropriate selection and dosing of induction therapy can prevent acute rejection episodes, postpone the onset of acute rejection outside the critical perioperative period, potentially decrease the degree of ischemia-reperfusion injury, and graft function $[5,6]$. The latter has become increasingly important as major transplant centers continue to utilize marginal donor kidneys, including expanded criteria donors (ECD) and donation after cardiac death (DCD) donors. Additionally, induction therapy has benefited patients at higher risk of acute rejection, including those that are highly sensitized, African American, or undergoing retransplantation $[7,8]$. Nevertheless, despite the decrease in acute rejection episodes and improvement in early graft function, overall allograft survival has not been clearly shown to improve with induction therapy.

Induction therapy commonly refers to antibodies against specific or non-specific antigens on targeted immune cells (Table 1). These can be classified as lymphocyte depleting agents and non-lymphocyte depleting agents. The categorization is based on the ability of the therapeutic agent to target specific antigens or cells, leading to a decrease in the total cellular expression or reduction in cell counts. Most depleting agents are relatively potent with potential for toxicity with prolonged administration (i.e. OKT3). On the other hand, nondepleting agents are generally well-tolerated with reasonable side effect profiles, yet are less potent (i.e. anti-interleukin-2 receptor antibody). Depleting agents are also used for severe or refractory cases of acute rejection and have proven to be more effective than glucocorticoids in treating these episodes of acute rejection [9]. Polyclonal antibodies are typically heterogeneous, with batch-to-batch variability, variable in vivo reactions, typically require larger doses, and are less susceptible to immune elimination (Figure 1). Monoclonal antibodies are more consistent, predictable, and require smaller doses. Murine monoclonal antibodies are susceptible to immune elimination, but chimeric (e.g. basiliximab) and especially humanized (e.g. alemtuzumab, daclizumab) antibodies are less susceptible to immune elimination. Some major institutions have modified their immunosuppression regimen to avoid long-term steroid maintenance. These regimens have utilized more potent induction agents (i.e. rabbit Antithymocyte globulin [rATG]) even in higher risk patients, such as the elderly or patients with multiple co-morbidities. The armamentarium of induction agents in modern transplantation has expanded, leading to the clinical dilemma in selecting the most appropriate agent for a given patient while taking into account co-morbidities, donor quality, immunological status, and planned maintenance therapy.

The importance of induction therapy compared to transplantation without induction therapy has been clearly demonstrated and routinely accepted. The following review focuses on the three most commonly used induction agents in modern kidney transplantation, including rATG, basiliximab, and alemtuzumab. The advantages

${ }^{*}$ Corresponding author: Cheguevara Afaneh, MD, Department of Surgery, Weill Cornell Medical College, New York Presbyterian Hospital, 525 East $68^{\text {th }}$ Street, Box 44, Tel. 212-746-5330; Fax: 212-746-6890; E-mail: cafaneh@gmail.com

Received November 08, 2011; Accepted December 16, 2011; Published December 20, 2011

Citation: Afaneh C, Aull MJ, Schubl S, Leeser DB, Kapur S (2011) Induction Therapy: A Modern Review of Kidney Transplantation Agents. J Transplant Technol Res S4:001. doi:10.4172/2161-0991.S4-001

Copyright: (c) 2011 Ferchichi $\mathrm{H}$, et al. This is an open-access article distributed under the terms of the Creative Commons Attribution License, which permits unrestricted use, distribution, and reproduction in any medium, provided the original author and source are credited. 
Citation: Afaneh C, Aull MJ, Schubl S, Leeser DB, Kapur S (2011) Induction Therapy: A Modern Review of Kidney Transplantation Agents. J Transplant Technol Res S4:001. doi:10.4172/2161-0991.S4-001

Page 2 of 7

\begin{tabular}{|c|c|c|c|c|c|c|}
\hline Agent & Clonality & Targets & Dosing & Halflife & Duration of effects & $\begin{array}{l}\text { Cytokine Release } \\
\text { Syndrome? }\end{array}$ \\
\hline rATG $^{1}$ & Polyclonal & Various immune targets, especially $\mathrm{T}$ cells & Multiple doses (POD²\#0-4) & 29.8-37.7 days & Months to years & Yes \\
\hline Basiliximab & Monoclonal & CD25 (predominantly activated T cells) & 2 doses (POD²\#0 \& 4) & 7.2 days & Weeks & No \\
\hline Daclizumab & Monoclonal & CD25 (predominantly activated T cells) & $\begin{array}{l}\text { Multiple doses (POD²\#0, } \\
\text { then every } 2 \text { weeks) }\end{array}$ & 20 days & Weeks & No \\
\hline Alemtuzumab & Monoclonal & CD52 (naïve T cells, some B cells, and monocytes) & Typically 1 dose (POD²\#0) & 12 days & Months to years & Yes (less than rATG ${ }^{1}$ ) \\
\hline
\end{tabular}

${ }^{1}$ rATG: Rabbit Antithymocyte Globulin; ${ }^{2}$ POD: Post Operative Day

Table 1: Pharmacological Comparison of Induction Therapy.
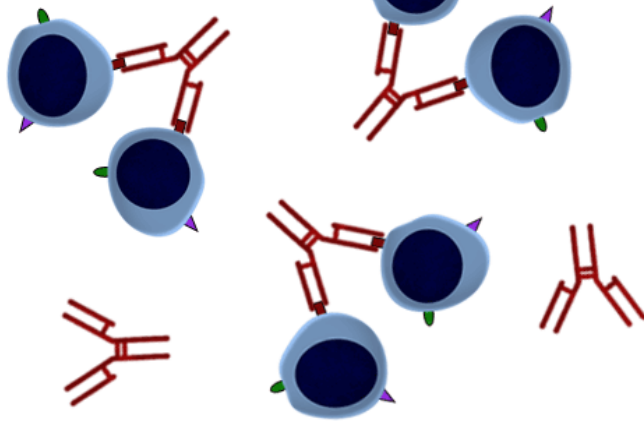

MONOCLONAL

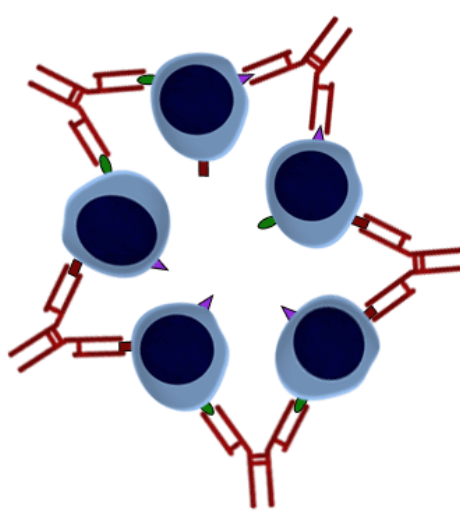

POLYCLONAL

Figure 1: Monoclonal versus Polyclonal Antibodies. Monoclonal antibodies are specific and bind a single antigen as shown on the left in the figure. Polyclonal antibodies are non-specific and bind multiple antigens as shown on the right in the figure.

and disadvantages of each agent will be discussed in the following review in the context of tailoring induction therapy to specific patient populations.

\section{Rabbit-Antithymocyte Globulin (rATG)}

Although several polyclonal depleting antibodies are commercially available, rATG remains the most commonly utilized therapeutic induction agent, although not specifically approved for this indication. This heterologous polyclonal antibody formulation is created by immunizing rabbits with human thymocytes, which act as immunogens [10]. Rabbit serum is gathered and purified, leaving only the IgG isotypes. Given the non-specificity of this process, multiple intended and non-intended antigens are targeted. rATG can bind CD2, CD3, CD4, CD5, CD8, CD11a, CD18, CD28, CD45, and CD40L on T cells, as well as CD16, CD20, CD56, and the major histocompatibility molecules (class I and II) $[10,11]$. T cell depletion is critical to the efficacy of rATG; however, the exact assortment of mechanisms of this agent is not fully understood. The bound T cells are cleared via the reticuloendothelial system of the spleen and liver [12]. The effects of lymphocyte depletion can persist for months to years, as the serum half-life of rATG is at least several weeks [13-15]. rATG has been used as both induction therapy (off-label) and FDA-approved treatment modality for acute rejection.

Rabbit ATG is most effective when the first dose is administered prior to vascular anastamosis at the time of allograft transplantation. Ensuring timely dosing can minimize ischemia-reperfusion injury and mitigate the development of delayed graft function (DGF) [16]. The typical dosing regimen for $\mathrm{rATG}$ is $1.5 \mathrm{mg} / \mathrm{kg} /$ dose for 3 to 5 days with an optimal dose of $6 \mathrm{mg} / \mathrm{kg}$ [17-20]. Nevertheless, various protocols have included a variety of dosing regimens from 1 to $6 \mathrm{mg} / \mathrm{kg} / \mathrm{dose}$ given anywhere from 1 to 10 days [13,17-20]. These include infectious complications, such as cytomegalovirus (CMV), herpes simplex virus (HSV), Epstein-Barr virus (EBV), and varicella, as well as lymphomas, such as post-transplant lymphoproliferative disorder (PTLD) [21,22].
The first infusion of rATG can elicit flu-like symptoms in addition to an allergic reaction. The mildest form of this reaction simply includes fever and chills; however, this may lead to a syndrome called cytokine release syndrome (Figure 2), which is common to many lymphocyte depleting polyclonal antibodies. Cytokine release syndrome can also include various vague symptoms, such as nausea, urticaria, rash, and headache; however, more severe cases can include the development of dyspnea, hypotension, pulmonary edema, or even anaphylaxis $[10,23]$. In a prospective randomized study examining single bolus antithymocyte globulin $(9 \mathrm{mg} / \mathrm{kg} /$ dose $)$ compared to basiliximab, patients treated with the single bolus antithymocyte globulin had a lower rate of delayed graft function $(5.7 \%$ versus $15.9 \%$ in the basilximab-treated group, $\mathrm{P}<0.025)$; however, experienced significant hemodynamic and pulmonary disturbances without significantly reducing the incidence of acute rejection, improving patient or graft survival [24]. Given the potential for such side effects, patients with significant pulmonary or cardiac disease may not be suitable candidates to receive $\mathrm{rATG}$, as their physiologic reserve is limited. Premedicating the patient with corticosteroids, acetaminophen, and antihistamine prior to initial infusions as well as slow administration of rATG via a central venous catheter can significantly reduce the occurrence and/ or intensity of cytokine release syndrome. Following administration of rATG patients should be monitored daily for leucopenia, neutropenia, and thrombocytopenia which are typically dose-related and generally resolve within days following dose reduction [25]. Global overimmunosuppression has been linked to both CMV infection, which is most prevalent in the first year posttransplant, and malignancies, such as PTLD [26]. Infectious prophylaxis is necessary given the significant immunosuppression associated with rATG, thus patients are usually maintained on antiviral, antibacterial, and antifungal prophylaxis in the perioperative period and when the agent is being administered for an episode of acute rejection. 
Citation: Afaneh C, Aull MJ, Schubl S, Leeser DB, Kapur S (2011) Induction Therapy: A Modern Review of Kidney Transplantation Agents. J Transplant Technol Res S4:001. doi:10.4172/2161-0991.S4-001

Page 3 of 7

\begin{tabular}{|c|c|c|c|c|c|c|c|c|}
\hline Author & $\begin{array}{l}\text { No. of } \\
\text { Patients }\end{array}$ & $\begin{array}{l}\text { Induction } \\
\text { Therapy }\end{array}$ & $\begin{array}{l}\text { Maintenance } \\
\text { Therapy }\end{array}$ & $\begin{array}{l}\text { Acute Rejection } \\
\text { at } 1 \text { year }\end{array}$ & Patient Survival & Graft Survival & Infections & Other \\
\hline $\begin{array}{l}\text { Brennan et } \\
\text { al. [7] }\end{array}$ & $\begin{array}{l}141 \\
137\end{array}$ & $\begin{array}{l}\text { rATG } \\
\text { Basiliximab }\end{array}$ & $\begin{array}{l}\text { Csa } \\
\text { MMF } \\
\text { Prednisone }\end{array}$ & $\begin{array}{l}\text { rATG: } 15.6 \% \\
\text { Basiliximab: } \\
25.5 \% \\
P=0.02\end{array}$ & $\begin{array}{l}\text { At } 1 \text { year: } \\
\text { rATG: } 95.7 \% \\
\text { Basiliximab: } \\
95.6 \% \\
\text { No significant } \\
\text { difference }\end{array}$ & $\begin{array}{l}\text { At } 1 \text { year: } \\
\text { rATG: } 90.8 \% \\
\text { Basiliximab: } \\
89.8 \% \\
\text { No significant } \\
\text { difference }\end{array}$ & $\begin{array}{l}\text { rATG: } 85.8 \% \\
\text { Basiliximab: } \\
75.2 \% \\
P=0.03\end{array}$ & $\begin{array}{l}\text { No difference in incidence } \\
\text { of cancer between the } \\
\text { groups }\end{array}$ \\
\hline $\begin{array}{l}\text { Cantarovich et } \\
\text { al. [57] }\end{array}$ & $\begin{array}{l}99 \text { CSWD } \\
98 \mathrm{CCS}\end{array}$ & $\begin{array}{l}\text { rATG } \\
\text { rATG }\end{array}$ & $\begin{array}{l}\text { Csa } \\
\text { MMF } \\
+/- \text { prednisone }\end{array}$ & $\begin{array}{l}\text { At } 1 \text { year: } \\
\text { CSWD: } 17.3 \% \\
\text { CCS: } 7.1 \% \\
P=0.031\end{array}$ & $\begin{array}{l}\text { At } 1 \text { year: } \\
\text { CSWD: } 97.1 \% \\
\text { CCS: } 99.0 \% \\
\begin{array}{l}\text { No significant } \\
\text { difference }\end{array}\end{array}$ & $\begin{array}{l}\text { At } 1 \text { year: } \\
\text { CSWD: } 94.9 \% \\
\text { CCS: } 93.2 \% \\
\text { No significant } \\
\text { difference }\end{array}$ & $\begin{array}{l}\text { At } 1 \text { year: } \\
\text { CSWD: } 67.3 \% \\
\text { CCS: } 72.8 \% \\
\begin{array}{l}\text { No significant } \\
\text { difference }\end{array}\end{array}$ & $\begin{array}{l}\text { The CCS group had a trend } \\
\text { towards a higher incidence } \\
\text { of malignancy at } 1 \text { year } \\
(P=0.059) \text {. }\end{array}$ \\
\hline $\begin{array}{l}\text { Cianco et al. } \\
{[59]}\end{array}$ & $\begin{array}{l}100 \\
100\end{array}$ & $\begin{array}{l}\text { rATG/DAC } \\
\text { rATG/C1H }\end{array}$ & $\begin{array}{l}\text { FK } \\
\text { EC-MPS }\end{array}$ & $\begin{array}{l}\text { rATG/DAC: } 11 \% \\
\text { rATG/C1H: } 9 \% \\
\begin{array}{l}\text { No significant } \\
\text { difference }\end{array}\end{array}$ & $\begin{array}{l}\text { At } 4 \text { years: } \\
\text { rATG/DAC: } \\
96 \% \\
\text { rATG/C1H: } 92 \% \\
\begin{array}{l}\text { No significant } \\
\text { difference }\end{array}\end{array}$ & $\begin{array}{l}\text { At } 4 \text { years: } \\
\text { rATG/DAC: } \\
91 \% \\
\text { rATG/C1H: } 83 \% \\
\text { No significant } \\
\text { difference }\end{array}$ & $\begin{array}{l}\text { At } 1 \text { year: } \\
\text { rATG/DAC: } 22 \% \\
\text { rATG/C1H: } 21 \% \\
\text { No significant } \\
\text { difference }\end{array}$ & $\begin{array}{l}\text { No cases of PTLD occurred } \\
\text { in either group }\end{array}$ \\
\hline $\begin{array}{l}\text { Hanaway et al. } \\
{[51]}\end{array}$ & $\begin{array}{l}251: \\
70 \text { high risk } \\
164 \text { low risk } \\
69 \\
171\end{array}$ & $\begin{array}{l}\mathrm{C} 1 \mathrm{H} \\
\text { (high and low } \\
\text { risk patients) } \\
\text { rATG (high risk } \\
\text { patients only) } \\
\text { Basiliximab (low } \\
\text { risk patients } \\
\text { only) }\end{array}$ & $\begin{array}{l}\text { FK } \\
\text { MMF } \\
\text { Early steroid } \\
\text { withdrawal }\end{array}$ & $\begin{array}{l}\text { Low risk } \\
\text { patients: } \\
\text { C1H vs. } \\
\text { basiliximab } \\
\text { (3\% vs. } 20 \%, \\
\text { P<0.001) } \\
\\
\text { High risk } \\
\text { patients: } \\
\text { C1H vs. rATG } \\
(11 \% \text { vs. } 13 \%, \\
P=0.53)\end{array}$ & $\begin{array}{l}\text { At } 3 \text { years: } \\
\text { C1H } 96 \% \\
\text { Basiliximab } \\
98 \% \\
\text { rATG } 91 \% \\
\begin{array}{l}\text { No significant } \\
\text { difference }\end{array}\end{array}$ & $\begin{array}{l}\text { At } 3 \text { years: } \\
\text { C1H } 95 \% \\
\text { Basiliximab } \\
94 \% \\
\text { rATG 91\% } \\
\begin{array}{l}\text { No significant } \\
\text { difference }\end{array}\end{array}$ & $\begin{array}{l}\text { Serious Events } \\
\text { at } 3 \text { years } \\
\text { Low risk } \\
(\mathrm{P}=0.02) \text { : } \mathrm{C} 1 \mathrm{H} \\
35 \% \\
\text { Basiliximab } 22 \% \\
\\
\text { High risk } \\
(\mathrm{P}=0.009) \text { : } \\
\text { C1H } 60 \% \\
\text { rATG } 80 \%\end{array}$ & $\begin{array}{l}\text { Incidence of cancer was } \\
\text { significantly higher in the } \\
\text { C1H group compared } \\
\text { to rATG or basiliximab } \\
(P=0.03)\end{array}$ \\
\hline $\begin{array}{l}\text { Lebranchu et } \\
\text { al. [33] }\end{array}$ & $\begin{array}{l}50 \\
50\end{array}$ & $\begin{array}{l}\text { rATG } \\
\text { Basiliximab }\end{array}$ & $\begin{array}{l}\text { Csa } \\
\text { MMF } \\
\text { Prednisone } \\
\text { (withdrawn at } 6 \\
\text { months) }\end{array}$ & $\begin{array}{l}\text { rATG: } 8 \% \\
\text { Basiliximab: } \\
10 \% \\
\text { No significant } \\
\text { difference }\end{array}$ & $\begin{array}{l}\text { At } 1 \text { year: } \\
\text { rATG: } 100 \% \\
\text { Basiliximab: } \\
98 \% \\
\begin{array}{l}\text { No significant } \\
\text { difference }\end{array}\end{array}$ & $\begin{array}{l}\text { At } 1 \text { year: } \\
\text { rATG: } 96 \% \\
\text { Basiliximab: } \\
94 \% \\
\begin{array}{l}\text { No significant } \\
\text { difference }\end{array}\end{array}$ & $\begin{array}{l}\text { At } 1 \text { year: } \\
\text { rATG: } 86.0 \% \\
\text { Basiliximab: } \\
64.7 \% \\
\text { No significant } \\
\text { difference }\end{array}$ & $\begin{array}{l}\text { No cases of cancer } \\
\text { occurred in either group }\end{array}$ \\
\hline $\begin{array}{l}\text { Mourad et al. } \\
{[35]}\end{array}$ & $\begin{array}{l}53 \\
52\end{array}$ & $\begin{array}{l}\text { rATG } \\
\text { Basiliximab }\end{array}$ & $\begin{array}{l}\text { Csa } \\
\text { MMF } \\
\text { Prednisone }\end{array}$ & $\begin{array}{l}\text { rATG: } 9.4 \% \\
\text { Basiliximab: } \\
9.6 \% \\
\text { No significant } \\
\text { difference }\end{array}$ & $\begin{array}{l}\text { At } 1 \text { year: } \\
\text { rATG: } 98.1 \% \\
\text { Basiliximab: } \\
98.1 \% \\
\begin{array}{l}\text { No significant } \\
\text { difference }\end{array}\end{array}$ & $\begin{array}{l}\text { At } 1 \text { year: } \\
\text { rATG: } 96.2 \% \\
\text { Basiliximab: } \\
94.2 \% \\
\text { No significant } \\
\text { difference }\end{array}$ & $\begin{array}{l}\text { At } 1 \text { year: } \\
\text { rATG: } 53.0 \% \\
\text { Basiliximab: } \\
42.3 \% \\
\text { No significant } \\
\text { difference }\end{array}$ & $\begin{array}{l}\text { No cases of PTLD occurred } \\
\text { in either group }\end{array}$ \\
\hline $\begin{array}{l}\text { Woodle et al. } \\
{[37]}\end{array}$ & $\begin{array}{l}\text { CSWD } \\
\text { group } \\
(n=191) \\
\text { CCS group } \\
(n=195)\end{array}$ & $\begin{array}{l}\text { rATG } \\
125 \text { CSWD } \\
136 \text { CCS } \\
\text { IL-2RA } \\
66 \text { CSWD } \\
59 \text { CCS }\end{array}$ & $\begin{array}{l}\text { FK } \\
\text { MMF } \\
\text { +/- prednisone }\end{array}$ & $\begin{array}{l}\text { CSWD: } \\
\text { rATG: } 14.4 \% \\
\text { Basiliximab: } \\
24.2 \% \\
P=0.09 \\
\text { At } 5 \text { years: } \\
\text { CSWD: } 17.8 \% \\
\text { CCS: } 10.8 \% \\
P=0.058\end{array}$ & $\begin{array}{l}\text { At } 5 \text { years: } \\
\text { CSWD: } 94.2 \% \\
\text { CCS: } 93.3 \%\end{array}$ & $\begin{array}{l}\text { At } 5 \text { years: } \\
\text { CSWD: } 94.2 \% \\
\text { CCS: } 96.4 \%\end{array}$ & $\begin{array}{l}\text { CSWD: } 39.3 \% \\
\text { CCS: } 44.1 \% \\
\text { No significant } \\
\text { difference }\end{array}$ & $\begin{array}{l}\text { No difference in incidence } \\
\text { of cancer between the } \\
\text { CSWD and CCS groups }\end{array}$ \\
\hline
\end{tabular}

Table 2: Summary of Induction Therapy Trials and Agent Comparisons.

\section{Basiliximab}

Basiliximab is one of the most commonly utilized non-depleting monoclonal antibody induction agents. Basiliximab is a chimeric mouse-human monoclonal IgG1 antibody to the $\alpha$-subunit of the IL-2 receptor, or CD25. Inhibition of IL-2 binding to the intended receptor occurs through steric hindrance, which does not lead to lymphocyte depletion, but rather prevention of early T cell activation [27]. Since basiliximab is partially humanized and targets activated $\mathrm{T}$ cells exhibiting CD25 on the cell-surface, it is generally well tolerated with a favorable side effect profile. Because of its specificity for naïve T cells, basiliximab should be limited to induction therapy use only, as it is not efficacious for treatment of acute rejection.

In contrast to $\mathrm{rATG}$, basiliximab is administered only twice in the perioperative period ( $20 \mathrm{mg}$ per dose). The first dose is administered 
immediately prior to implantation of the transplant and the second dose on postoperative day 4 . Basiliximab can be safely administered via a peripheral line. According to Kovarik et al. [28], this regimen effectively achieves maintenance drug concentrations for a mean of 36 \pm 14 days, independent of age, gender, weight, and ethnicity. The most serious adverse event associated with basiliximab administration is hypersensitivity, which is rare $(<1 \%)$ [27]. There is data to suggest that basiliximab does not carry an increased risk of infectious complications or PTLD when compared to using no induction therapy, although some have shown an increased risk of CMV [29]. Overall, basiliximab is well tolerated and safe, even in patients with significant cardiac or pulmonary disease.

Basiliximab has been extensively studied in kidney transplantation. When compared to placebo, basiliximab has been shown to decrease the rate of acute rejection [30,31]. In a meta-analysis of various randomized clinical trials, patients treated with basiliximab had an odds ratio of 0.51 (confidence interval, 0.42 to 0.63 ) of experiencing an episode of acute rejection in the first 6 months compared to placebo $(\mathrm{P}<0.001)$, without an increase in infectious complications or risk of malignancy [32]. Several studies have compared basiliximab to polyclonal antibody depleting induction agents with patients maintained on triple-drug maintenance immunosuppression regimens (Table 2), demonstrating similar outcomes regarding the incidence of acute rejection and delayed graft function [33-35]. Lebranchu et al. [33] compared rATG to basiliximab in a series of 100 low immunologic risk kidney transplant recipients and found similar rates of acute rejection, while the rATG treated group experienced a higher incidence of CMV following treatment. At 5 years follow-up, patient and graft survival were similar as well as the incidence of acute rejection [34]. A large, prospective, multicenter randomized controlled trial followed 178 consecutive kidney transplant recipients at risk for poor outcomes (Table 2). Increased risk factors included allografts with cold ischemia times $>24$ hours, older donors (age $>50$ years), terminal serum creatinine $>2.5 \mathrm{mg} / \mathrm{dl}$, DCD donors, donors requiring high-dose inotropic support, as well as recipient risk factors including African American race, retransplants, panel-reactive antibody (PRA) $>20 \%$, or those with one or more HLA mismatches [7]. Patients were randomly assigned to receive either basiliximab or rATG induction therapy and the rATG-treated group had a lower incidence of acute rejection at 1

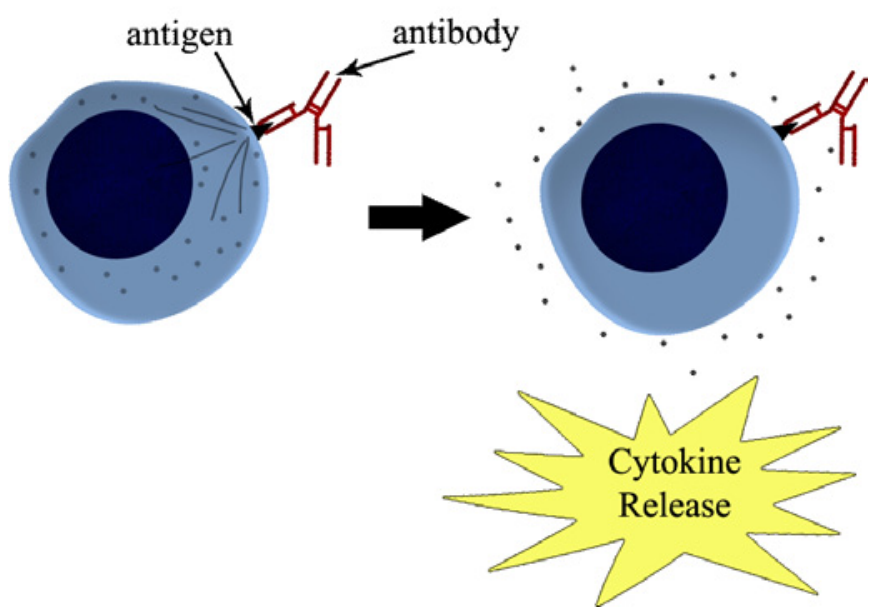

Figure 2: Cytokine Release Syndrome. Antibody activation and cytokine release. Antibodies can bind antigens resulting in activation of the cell and cytokine release as illustrated in the figure. year compared to the basiliximab-treated group (15.6\% versus $25.6 \%$, respectively, $P=0.02$ ). Patients in the rATG-treated group experienced a higher rate of infectious complications $(\mathrm{P}=0.02)$ while conversely the rate of CMV infection was significantly higher in the basiliximabtreated group $(\mathrm{P}=0.02)$. The incidence of delayed graft function and malignancy, including PTLD, was not significantly different between the two groups. Subsequently, a long-term follow-up of this study with 60 months of data was published and demonstrated a sustained difference in the cumulative incidence of acute rejection; though patient and graft survival were not significantly different [36]. Basiliximab has been demonstrated to be effective in steroid-free immunosuppression regimens as well (Table 2) [37,38], although this will be discussed later.

\section{Daclizumab}

Similar to basiliximab, daclizumab is an antagonist to CD25; however, it is a humanized IgG1 antibody. The CD25 molecule was the first humanized monoclonal antibody to be successfully targeted in the field of transplantation $[39,40]$. The mechanism of action of daclizumab essentially duplicates that of other IL-2 receptor antagonists.

Like basiliximab, daclizumab has been shown to decrease the incidence of acute cellular rejection when administered as an induction agent [41-43]. Given the favorable side effect profile, it is tolerated well in recipients, irrespective of co-morbid conditions. The main disadvantage of daclizumab, as compared to basiliximab, is that it is more costly and requires repeated administrations [44]. Because the demand for the medication has been relatively low, it has been discontinued by the manufacturer. It has no role as a rescue agent for acute rejection.

The side effect profile is similar to that of basiliximab and generally favorable. Cytokine release is not typically associated with this agent $[41,42]$. Like other IL-2 receptor antagonists, the risk of PTLD is not significantly increased with use [29].

\section{Alemtuzumab}

Alemtuzumab, also known as Campath-1H or Lemtrada, is an IgG1 humanized rat monoclonal antibody directed against the cell surface glycoprotein CD52, which is present in high abundance on $\mathrm{T}$ cells, B cells, and monocytes [45]. The net effect ultimately leads to significant depletion of all $\mathrm{T}$ cell subsets (especially naïve $\mathrm{T}$ cells), various B cells, as well as monocytes, not only in the peripheral circulation, but also the allograft [46,47]. Although memory T cells are less susceptible to alemtuzumab's depletory effects, calcineurin inhibitors are effective on these remaining T cell subsets. Thus, patients with delayed graft function may benefit from alemtuzumab induction, as calcineurin inhibitor use can be postponed until allograft function returns. Importantly, however, alemtuzumab may have limited efficacy in sensitized patients, as these patients may have a significantly larger proportion of memory $\mathrm{T}$ cells.

Alemtuzumab is relatively easy to administer while generating a potent effect in a relatively short period of time. The typical dose is $30 \mathrm{mg}$ or $0.3 \mathrm{mg} / \mathrm{kg}$ administered through a peripheral line over 3 hours. Like basiliximab, alemtuzumab does not require daily dosing, as it is typically administered only once after which T cells are depleted within 1 hour, although a second dose is sometimes given [46,47] Lymphocyte depletion lasts for months to years, as the immune system is reconstituted [27]. Like rATG, alemtuzumab may be associated with cytokine release syndrome, though to a lesser extent. Patients are typically premedicated with methylprednisolone, acetaminophen, and diphenhydramine to blunt the cytokine release response. Common side effects include fever, chills, urticaria and rash; however, 
hypotension and anaphylaxis have also been reported. Early studies utilizing alemtuzumab for multiple sclerosis was associated with the development of autoimmune thyroiditis [48] and similar findings have been noted in a renal transplant patient undergoing alemtuzumab induction therapy [49].

Alemtuzumab is only FDA-approved for the treatment of lymphogenerative malignancies, although a common off-label use is induction therapy. Initial studies utilizing alemtuzumab for the treatment of acute rejection demonstrated significant infectious morbidity and mortality in patients maintained on triple maintenance immunosuppression therapy [50]. A recent prospective study (Table 2) compared the short-term results of alemtuzumab induction therapy to rATG and basiliximab in patients maintained on a steroid-sparing immunosuppression regimen [51]. Short-term data demonstrated lower rates of acute rejection at 6 months for patients at low-risk of developing acute rejection receiving alemtuzumab therapy compared with those receiving basiliximab. There was no difference in acute rejection rates between high immunologic risk patients receiving alemtuzumab versus those receiving rATG at 3 years. Patients receiving alemtuzumab did not experience an increased rate of adverse events. However, patients were excluded if they received kidneys from expanded-criteria donors, donation after cardiac death kidneys, and standard-criteria donors from kidneys with prolonged cold-ischemia times. Furthermore, the majority of transplants came from living donors, which traditionally have low rates of acute rejection. In the post hoc analysis alemtuzumab-treated patients had a trend toward higher rates of acute rejection compared to conventional induction agents between 1 and 3 years and the overall acute rejection risk reduction of alemtuzumab, compared to conventional induction therapy, was greatest in patients at low-risk of acute rejection.

\section{Induction Therapy and the Steroid-Free Era}

Minimizing global immunosuppression in the modern era of transplantation has become an important goal. The use of induction therapy has allowed for steroid-free long-term immunosuppression regimens and is gaining popularity world-wide. The goal of steroid-free immunosuppression is to decrease the negative cardiovascular profile associated with long-term administration of steroids. Specifically, steroid-free regimens should decrease the negative effects on blood pressure regulation as well serum glucose and lipid metabolism [52]. Moreover, the leading cause of death in kidney transplant patients is cardiovascular events [53].

The possible minimization of maintenance immunosuppression has been studied using basiliximab and rATG without compromising allograft outcomes. In the Astellas Steroid Withdrawal Study, patients assigned to the steroid-withdrawal arm and treated with rATG experienced a lower cumulative incidence of biopsy-proven acute rejection at 5 years compared to patients treated with basiliximab (Table 2) [37]. In this study, however, the investigators selected which antibody induction agent was used, thus raising the possibility that bias may have been introduced. In a smaller study using a steroid-avoidance immunosuppression regimen in HLA-matched donor/recipient pairs, basiliximab use has not lead to an increase in acute rejection episodes or the development of delayed graft function [38]. Moreover, only 1 patient (4\%) developed post-transplant diabetes mellitus. In a study by Jaber et al. [54], kidney transplant recipients treated with rATG induction therapy and steroid-free immunosuppression demonstrated a cardiovascular risk factor reduction in four categories including the incidence of hypertension, hyperlipidemia, weight gain, and posttransplant diabetes mellitus, without compromising allograft survival or increasing the rate of acute rejection. Li and colleagues demonstrated the safety and efficacy of rATG and a steroid-free immunosuppression regimen in the pediatric population receiving a kidney transplant [55]. In this study, rATG was compared to an IL-2 receptor antibody utilizing a steroid-free regimen showing that rATG-treated patients did not develop acute rejection for the duration of the study or have an increased risk of clinical viral infection. Our transplant center's experience utilizing induction therapy to enable steroid withdrawal has been very successful in a diverse population, using rATG in the majority of patients [56] and basiliximab in well-matched living donor recipients [38]. Cantarovich and colleagues demonstrated that patients administered rATG and maintained on a steroid-maintenance regimen had significantly lower rates of acute rejection compared to patients on a steroid-free immunosuppression regimen, although the incidence of malignancy, de novo diabetes, and hyperlipidemia were higher in steroid-maintenance group [57]. Patient and graft survival rates, as well as infectious complications in the first year were not significantly different between the two cohorts.

Alemetuzumab has also been studied in a steroid-sparing immunosuppression regimen and compared to both basiliximab and rATG. In the study by Hanaway et al. [51] (Table 2) as previously described, acute rejection rates were relatively low in low-risk patients receiving alemtuzumab compared to basiliximab, although the reduced immunologic risk profile of alemtuzumab was not evident in high risk patients treated with rATG. The overall rate of adverse events with alemtuzumab treated patients was similar to that of basiliximab or rATG treated patients over the 3 year study period (53\% versus $50 \%$, respectively; $\mathrm{P}=0.46$ ). Moreover, the rate of cardiovascular events of all alemtuzumab treated patients compared to basiliximab or rATG was also similar ( $7 \%$ versus $10 \%$, respectively; $\mathrm{P}=0.26$ ), although the similarity was less evident in the high-risk immunologic group treated with rATG compared to alemtuzumab ( $12 \%$ versus $3 \%$, respectively; $\mathrm{P}=0.06$ ). Cai et al. [58] analyzed the United Network for Organ Sharing registry and found that recipients of alemtuzumab in conjunction with steroid-maintenance therapy had the lowest risk of graft failure, while patients administered an interleukin-2 receptor antagonist on a steroidfree immunosuppression regimen had the highest risk of graft failure. In a single-center, open-label randomized trial of 200 kidney transplant recipients (Table 2), Ciancio and colleagues compared dual induction therapy with rATG and daclizumab to dual therapy with rATG and alemtuzumab in patients maintained on steroid-free maintenance immunosuppression [59]. Lower doses of all induction therapy agents were used in both sets of patients. Patient and graft survival rates as well as acute rejection and infectious complication rates were not significantly different between the two groups. Moreover, none of these patients developed post-transplant lymphoproliferative disorder.

\section{Summary}

Induction therapy has become the standard of care at most major kidney transplant centers in the United States and abroad. The most frequently used agents include rATG, a polyclonal lymphocytedepleting agent, and basiliximab, a monoclonal interleukin-2 receptor antagonist; however, there is renewed interest in alemtuzumab, a monoclonal antibody to CD52. Although induction therapy has not improved long-term patient and allograft survival, it has decreased the incidence of acute rejection and delayed graft function, which have both been shown to increase morbidity and affect short-term allograft outcomes. Additionally, administration of induction therapy has improved early graft function. Furthermore, potent induction therapy has been effective in avoiding long-term steroid use in immunosuppression regimens without increasing acute rejection rates 
or compromising long-term allograft function. Importantly, tailoring immunosuppression to each an individual patient's needs remains the most effective method of improving allograft function and maximizing patient outcomes.

\section{References}

1. Szczech LA, Berlin JA, Aradhye S, Grossman RA, Feldman HI (1997) Effect of anti-lymphocyte induction therapy on renal allograft survival: a meta-analysis. J Am Soc Nephrol 8: 1771-1777.

2. Meier-Kriesche HU, Li S, Gruessner RW, Fung JJ, Bustami RT, et al. (2006) Immunosuppression: evolution in practice and trends, 1994-2004. Am J Transplant 6: 1111-1131.

3. Bustami RT, Ojo AO, Wolfe RA, Merion RM, Bennett WM, et al. (2004) Immunosuppression and the risk of post-transplant malignancy among cadaveric first kidney transplant recipients. Am J Transplant 4: 87-93.

4. Jamil B, Nicholls K, Becker GJ, Walker RG (1999) Impact of acute rejection therapy on infections and malignancies in renal transplant recipients. Transplantation 68: 1597-1603.

5. Bell PR, Blamey RW, Briggs JD, Castro JE, Hamilton DN, et al. (1983) Medical Research Council trial of antilymphocyte globulin in renal transplantation: A multicenter randomized double-blind placebo controlled clinical investigation. Transplantation 35: 539-545.

6. Mourad G, Garrigue V, Squifflet JP, Besse T, Berthoux F, et al. (2001) Induction versus noninduction in renal transplant recipients with tacrolimusbased immunosuppression. Transplantation 72: 1050-1055.

7. Brennan DC, Daller JA, Lake KD, Cibrik D, Del Castillo D, et al. (2006) Rabbit antithymocyte globulin versus basiliximab in renal transplantation. $N$ Engl J Med 355: 1967-1977

8. Gaston RS, Hudson SL, Deierhoi MH, Barber WH, Laskow DA, et al. (1992) Improved survival of primary cadaveric renal allografts in blacks with quadruple immunosuppression. Transplantation 53: 103-109.

9. Webster A, Pankhurst T, Rinaldi F, Chapman JR, Craig JC (2006) Polyclona and monoclonal antibodies for treating acute rejection episodes in kidney transplant recipients. Cochrane Database Syst Rev: CD004756.

10. Hardinger KL (2006) Rabbit antithymocyte globulin induction therapy in adult renal transplantation. Pharmacotherapy 26: 1771-1783.

11. Bonnefoy-Berard N, Vincent C, Revillard J (1991) Antibodies against the functional leukocyte surface molecules in polyclonal antilymphocyte and antithymocyte globulins. Transplantation 51: 669-673.

12. Padiyar A, Augustine JJ, Hricik DE (2009) Induction antibody therapy in kidney transplantation. Am J Kidney Dis 54: 935-944.

13. Brennan DC, Flavin K, Lowell JA, Howard TK, Shenoy S, et al. (1999) A randomized,double-blinded comparison of thymoglobulin versus Atgam for induction immunosuppressive therapy in adult renal transplant recipients. Transplantation 67: 1011-1018.

14. Hardinger KL, Schnitzler MA, Miller B, Lowell JA, Shenoy S, et al. (2004) Five-year follow up of thymoglobulin versus ATGAM induction in adult renal transplantation. Transplantation 78: 136-141.

15. Bunn D, Lea CK, Bevan DJ, Higgins RM, Hendry BM (1996) The pharmacokinetics of anti-thymocyte globulin (ATG) following intravenous infusion in man. Clin Nephrol 45: 29-32.

16. Shoskes DA, Halloran PF (1996) Delayed graft function in renal transplantation etiology, management and long-term significance. J Urol 155: 1831-1840.

17. Goggins WC, Pascual MA, Powelson JA, Magee C, Tolkoff-Rubin N, et al. (2003) A prospective, randomized, clinical trial of intraoperative versus postoperative Thymoglobulin in adult cadaveric renal transplant recipients. Transplantation 76: 798-802.

18. Agha IA, Rueda J, Alvarez A, Singer GG, Miller BW, et al. (2002) Short course induction immunosuppression with thymoglobulin for renal transplan recipients. Transplantation 73: 473-475.

19. Wong W, Agrawal N, Pascual M, Anderson DC, Hirsch HH, et al. (2006) Comparison of two dosages of thymoglobulin used as a short-course for induction in kidney transplantation. Transpl Int 19: 629-635.

20. Stevens RB, Mercer DF, Grant WJ, Freifeld AG, Lane JT, et al. (2008) Randomized trial of single-dose versus divided-dose rabbit anti-thymocyte globulin induction in renal transplantation: An interim report. Transplantation 85: 1391-1399.

21. Abott KC, Hypolite IO, Viola R, Poropatich RK, Hsieh P, et al. (2002) Hospitalizations for cytomegalovirus disease after renal transplantation in the United States. Ann Epidemiol 12: 402-409.

22. Gourishankar S, McDermid JC, Jhangri GS, Preiksaitis JK (2004) Herpes zoster infection following solid organ transplantation: incidence, risk factors and outcomes in the current immunosuppressive era. Am J Transplant 4: 108-115.

23. Guttmann RD, Caudrelier P, Alberici G, Touraine JL (1997) Pharmacokinetics foreign protein immune response, cytokine release, and lymphocyte subsets in patients receiving thymoglobuline and immunosuppression. Transplant Proc 29: $24 S-26 S$

24. Kyllönen LE, Eklund BH, Pesonen EJ, Salmela KT (2007) Single bolus antithymocyte globulin versus basiliximab induction in kidney transplantation with cyclosporine triple immunosuppression: efficacy and safety Transplantation 84: 75-82.

25. Gurk-Turner C, Airee R, Philosophe B, Kukuruga D, Drachenberg C, et al. (2008) Thymoglobulin dose optimization for induction therapy in high risk kidney transplant recipients. Transplantation 85: 1425-1430.

26. Opelz G, Dohler B (2003) Lymphomas after solid organ transplantation: A Collaborative Transplant Study report. Am J Transplant 4: 222-230.

27. Gabardi S, Martin ST, Roberts KL, Grafals M (2011) Induction immunosuppressive therapies in renal transplantation. Am J Health Sys Pharm 68: 211-218.

28. Kovarik JM, Kahan BD, Rajagopalan PR, Bennett W, Mulloy LL, et al. (1999) Population pharmacokinetics and exposure-response relationships for basiliximab in kidney transplantation. The U.S. Simulect Renal Transplant Study Group. Transplantation 68: 1288-1294.

29. Cherikh WS, Kauffman HM, McBride MA, Maghirang J, Swinnen LJ, et al. (2003) Association of the type of induction immunosuppression with posttransplan lymphoproliferative disorder, graft survival, and patient survival after primary kidney transplantation. Transplantation 76: 1289-1293.

30. Nashan B, Moore R, Amlot P, Schmidt AG, Abeywickrama K, et al. (1997) Randomised trial of basiliximab versus placebo for control of acute cellular rejection in renal allograft recipients. CHIB 201 International Study Group. Lancet 350: 1193-1198.

31. Kahan BD, Rajagopalan PR, Hall M (1999) Reduction of the occurrence of acute cellular rejection among renal allograft recipients treated with basiliximab, a chimeric antiinterleukin-2-receptor monoclonal antibody. United States Simulect Renal Study Group. Transplantation 67: 276-284.

32. Adu D, Cockwell P, Ives NJ, Shaw J, Wheatley K (2003) Interleukin-2 receptor monoclonal antibodies in renal transplantation: Meta-analysis of randomised trials. BMJ 326: 789-793.

33. Lebranchu Y, Bridoux F, Buchler M, Le Meur Y, Etienne I, et al. (2002) Immunoprophylaxis with basiliximab compared with antithymocyte globulin in renal transplant patients receiving MMF-containing triple therapy. Am J Transplant 2: 48-56.

34. Al Najjar A, Etienne I, Le Pogamp P, Bridoux F, Le Meur Y, et al. (2006) Long-term results of monoclonal anti-IL2-receptor antibody versus polyclonal antilymphocyte antibodies as induction therapy in renal transplantation. Transplant Proc 38: 2298-2299.

35. Mourad G, Rostaing L, Legendre C, Garrigue V, Thrvet E, et al. (2004) Sequential protocols using basiliximab versus antithymocyte globulins in renal-transplant patients receiving mycophenolate mofetil and steroids. Transplantation 78: 584-590.

36. Brennan DC, Schnitzler MA (2008) Long-term results of rabbit antithymocyte globulin and basiliximab induction. N Engl J Med 359: 1736-1738.

37. Woodle ES, First MR, Pirsch J, Shihab F, Gaber AO, et al. (2008) A prospective randomized, double-blind, placebo-controlled multicenter trial comparing early (7 day) corticosteroid cessation versus long-term, low-dose corticosteroid therapy. Ann Surg 248: 564-577.

38. Afaneh C, Halpern J, Cheng E, Aull M, Figueiro K, et al. (2010) Steroid avoidance in two-haplotype-matched living donor renal transplants with basiliximab induction therapy. Transplant Proc 42: 4526-4529.

39. Carswell Cl, Plosker GL, Wagstaff AJ (2001) Daclizumab: a review of its use in the management of organ transplantation. BioDrugs 15:745-773. 
Citation: Afaneh C, Aull MJ, Schubl S, Leeser DB, Kapur S (2011) Induction Therapy: A Modern Review of Kidney Transplantation Agents. J Transplant Technol Res S4:001. doi:10.4172/2161-0991.S4-001

Page 7 of 7

40. Kirkman RL, Shapiro ME, Carpenter CB, McKay DB, Milford EL, et al. (1991) A randomized prospective trial of anti-Tac monoclonal antibody in human renal transplantation. Transplantation 51: 107-113

41. Hershberger RE, Starling RC, Eisen HJ, Bergh CH, Kormmos RL, et al. (2005) Daclizumab to prevent rejection after cardiac transplantation. $\mathrm{N}$ Engl $\mathrm{J}$ Med 352: $2705-2713$

42. Nashan B, Light S, Hardie IR, Lin A, Johnson JR (1999) Reduction of acute renal allograft rejection by daclizumab. Daclizumab Double Therapy Study Group. Transplantation 67: 110-115.

43. Vincenti F, Kirkman R, Light S, Bumgardner G, Pescovitz M, et al. (1998) Interleukin-2-receptor blockade with daclizumab to prevent acute rejection in renal transplantation. Daclizumab Triple Therapy Study Group. N Engl J Med 338: 161-165.

44. Gabardi S, Martin ST, Roberts KL Grafals M (2011) Induction immunosuppressive therapies in renal transplantation. Am J Health Syst Pharm 68:211-218.

45. Hale G (2001) The CD52 antigen and development of the CAMPATH antibodies. Cytotherapy 3: 137-143

46. Kirk AD, Hale DA, Mannon RB, Kleiner DE, Hoffmann SC et al. (2003) Results from a human renal allograft tolerance trial evaluating the humanized CD52specific monoclonal antibody alemtuzumab (CAMPATH-1H). Transplantation 76: $120-129$

47. Pearl JP, Parris J, Hale DA, Hoffmann SC, Bernstein WB, et al. (2005) Immunocompetent T-cells with a memory-like phenotype are the dominant cell type following antibody-mediated T-cell depletion. Am J Transplant 5: 465-474

48. Coles AJ, Wing M, Smith S, Coraddu F, Greer S, et al. (1999) Pulsed monoclonal antibody treatment and autoimmune thyroid disease in multiple sclerosis. Lancet 354: 1691-1695.

49. Kirk AD, Hale DA, Swanson SJ, Mannon RB (2006) Autoimmune thyroid disease after renal transplantation using depletional induction with alemtuzumab. Am J Transplant 6: 1084-1085

50. Hale G, Waldmann H, Friend P, Calne R (1986) Pilot study of CAMPATH-1, a rat monoclonal antibody that fixes human complement, as an immunosuppressant in organ transplantation. Transplantation 42: 308-311.

51. Hanaway MJ, Woodle ES, Mulgaonkar S, Peddi VR, Kaufman DB, et al. (2011) Alemtuzumab induction in renal transplantation. New Engl J Med 364: 1909 1919.

52. Knight SR, Morris PJ (2010) Steroid avoidance or withdrawal after renal transplantation increases the risk of acute rejection but decreases cardiovascular risk: a meta analysis. Transplantation 89: 1-14.

53. Ojo AO, Hanson JA, Wolfe RA, Leichtman AB, Agodoa LY, et al. (2000) Long term survival in renal transplant recipients with graft function. Kidney Int 57 307-313

54. Jaber JJ, Feustel PJ, Elbahloul O, Conti AD, Gallichio MH, et al. (2007) Early steroid withdrawal therapy in renal transplant recipients: a steroid-free sirolimus and CellCept-based calcineurin inhibitor minimization protocol. Clin Transplant 21: 101-109.

55. Li L, Chaudhuri A, Chen A, Zhao X, Bezchinsky M, et al. (2010) Efficacy and safety of thymoglobulin induction as an alternative approach for steroidfree maintenance immunosuppression in pediatric renal transplantation. Transplantation 90: 1516-1520.

56. Aull MJ, Goldstein MJ, Dadhania D, Serur D, Kapur S (2006) Is steroid-sparing immunosuppression effective in a diverse patient population? Am J Transplan 82: 499-500.

57. Cantarovich D, Rostaing L, Kamar N, Saint-Hillier Y, Ducloux D, et al. (2010) Corticosteroid avoidance in adult kidney transplant recipients under rabbit anti-T-lymphocyte globulin, mycophenolate mofetil and delayed cyclosporine microemulsion introduction. Transpl Int 23: 313-324.

58. Cai J, Terasaki P (2010) Induction Immunosuppression Improves Long-Term Graft and Patient Outcome in Organ Transplantation: An Analysis of United Network for Organ Sharing Registry Data. Transplantation 90: 1511-1515.

59. Ciancio G, Gaynor JJ, Sageshima J, Guerra G, Zarak A, et al. (2011) Randomized trial of dual antibody induction therapy with steroid avoidance in renal transplantation. Transplantation 92: 1348-1357.
This article was originally published in a special issue, Immunosuppression in Transplantation handled by Editor(s). Dr. Johannes Schwartzkopff, AlbertLudwigs-University, Germany; Dr. Karoly Varga, University of Texas Medica School, USA 